\title{
An Assessment of Streamflow, Water Quality, and the Effects of Constructing an Impoundment on Bridge Creek at Augusta, Wisconsin
}

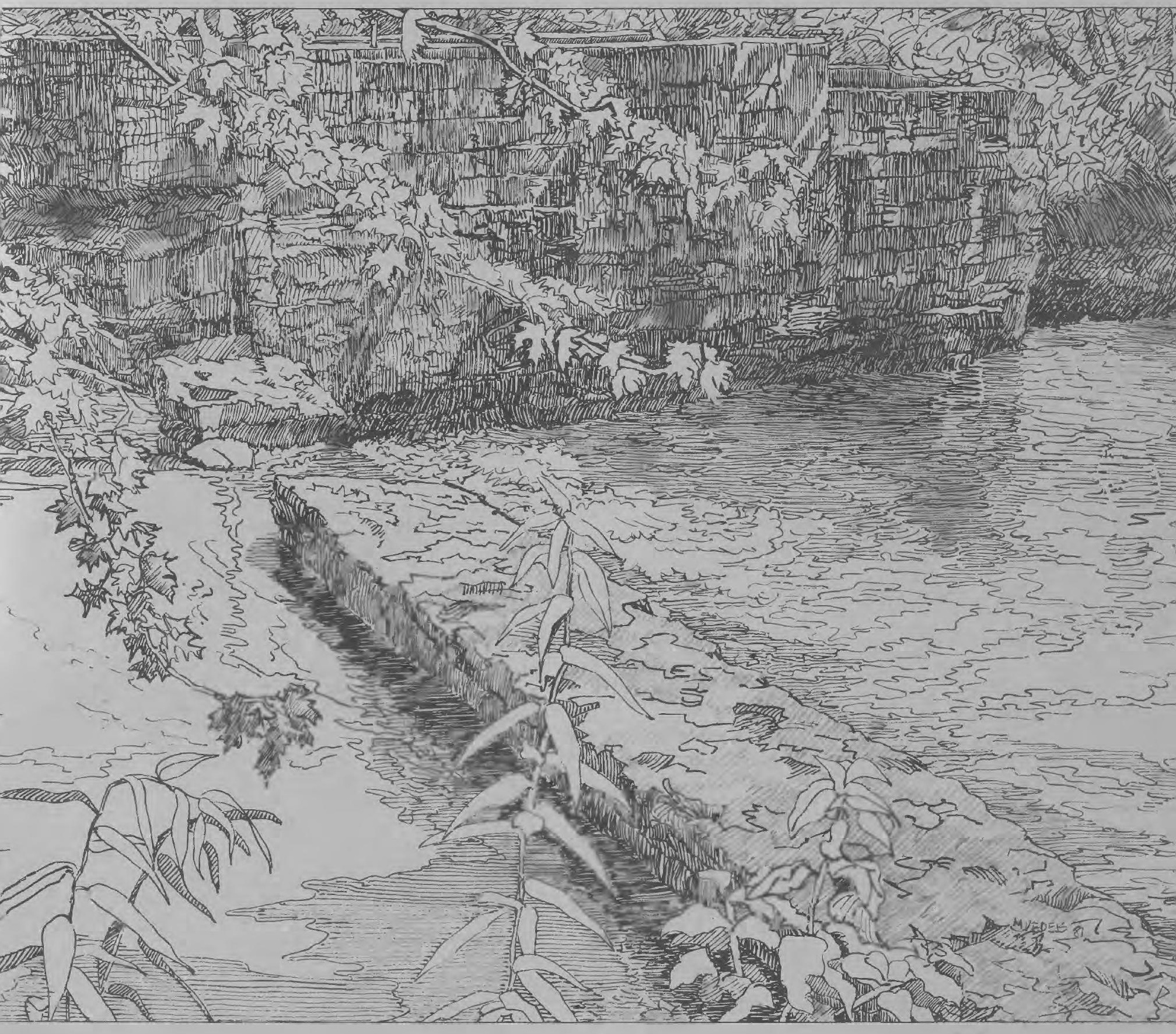




\title{
An Assessment of Streamflow, Water Quality, and the Effects of Constructing an Impoundment on Bridge Creek at Augusta, Wisconsin
}

\author{
by Leo B. House
}

Water-Resources Investigations

Open-File Report 81-1192

Prepared in cooperation with the

Wisconsin Department of Natural Resources

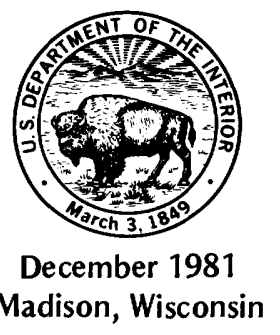




\title{
UNITED STATES DEPARTMENT OF THE INTERIOR
}

\author{
JAMES G. WATT, SECRETARY
}

\section{GEOLOGICAL SURVEY}

\author{
Dallas L. Peck, Director
}

For additional information write to:

U. S. Geological Survey

1815 University Avenue

Madison, Wisconsin 53706 


\section{CONTENTS}

$\underline{\text { Page }}$

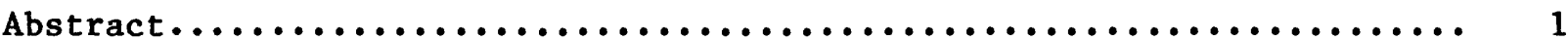

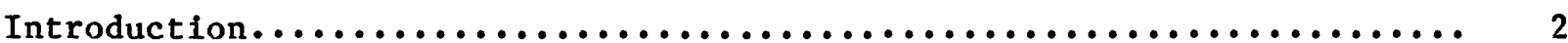

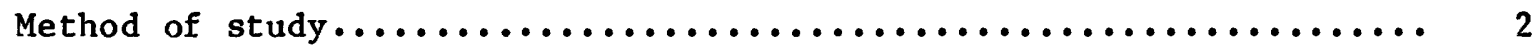

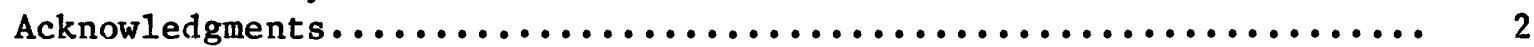

Description of the Bridge Creek basin.......................... 4

Streamflow characteristics of Bridge Creek..................... 5

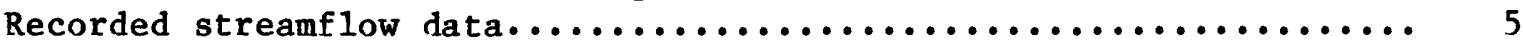

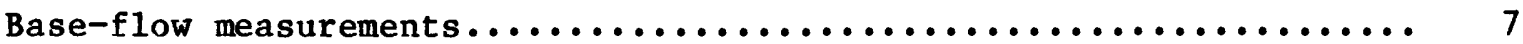

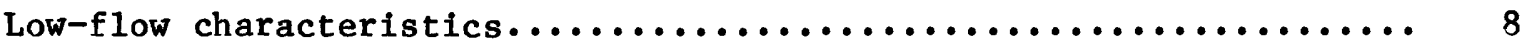

Water-quality data for Bridge Creek.......................... 8

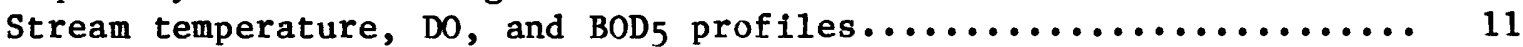

Water-chemistry data for Bridge Creek..................... 15

Description of proposed impoundment........................ 16

Effects of the proposed impoundment on water quality .............. 17

Computer simulation of the proposed impoundment water temperature

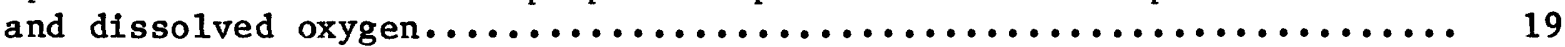

Simulation of downstream effects............................. 23

Summary and conclusions...................................... 24

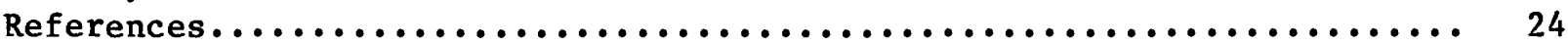

\section{ILLUSTRATIONS}

Plate 1. Drainage basin and base-flow measurement sites of Bridge Creek, Wis.

Figure 1. Location map for Bridge Creek at Augusta, Wis............ 3

2. Photograph showing USGS stream-gage and proposed damsite, Bridge Creek at Augusta, wis., spring $1980 \ldots \ldots \ldots \ldots \ldots \ldots \ldots$....... 5

3. Map showing stream temperature and dissolved-oxygen profile

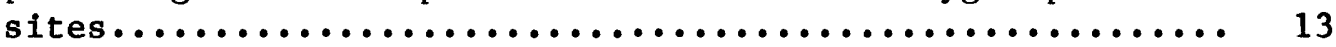

4. Graph showing surface area versus elevation curve for the proposed impoundment of Bridge Creek at Augusta, Wis.......

\section{DEFINITION OF TERMS}

Dissolved oxygen (DO) - the amount of oxygen, which is dependent upon the partial pressure of oxygen in the atmosphere, water temperature, and concentration of dissolved solids, dissoved in water expressed in $\mathrm{mg} / \mathrm{L}$ (milligrams per 1iter).

Biochemical oxygen demand (BOD) - usually defined as the amount of dissolved oxygen required by bacteria while stabilizing decomposable organic matter under aerobic conditions expressed in $\mathrm{mg} / \mathrm{L}$. BOD generally is measured during a period of 5 days ( $\left.\mathrm{BOD}_{5}\right)$. 


\section{TABLES}

Page

Table 1. Bridge Creek basin drainage areas...................... 4

2. Daily discharge records for Bridge Creek at Augusta......... 6

3. Bridge Creek basin base-flow measurements, July 9 and

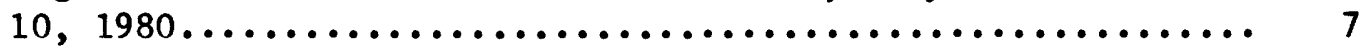

4. Summary of the continuous $D O$ and water-temperature data for Bridge Creek at Augusta, station no. 05366290............ 9

5. Periodic observations of water temperature, $\mathrm{DO}$, and $\mathrm{BOD}_{5} \ldots \ldots .10$

6. Stream temperature and DO measurement of Bridge Creek at

Augusta, July 9 and August 27, 1980................. 14

7. Chemical analysis of water from Bridge Creek at Augusta, Wis.. 16

8. DO and temperature in the Fall Creek impoundment, July 10,

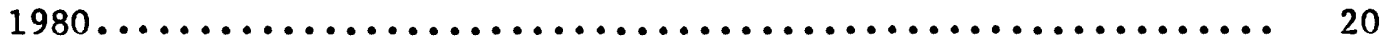

9. Comparison of simulated impoundment temperature and DO for Bridge Creek, July 11, $1980 \ldots \ldots \ldots \ldots \ldots \ldots \ldots \ldots \ldots \ldots \ldots . . . . \ldots 21$

10. Comparison of simulated daily average outflow temperature and Do.........................................

\section{CONVERSION TABLES}

For the use of readers who prefer the International System of Units (SI) (metric) rather than inch-pound units, the conversion factors for the terms used in this report are listed below.

$\underline{\text { Multiply }}$

acre

acre

acre-foot (acre-ft)

acre-foot per day

(acre-ft/day)

foot (ft)

mile (m1)

cubic foot per second $\left(\mathrm{ft}^{3} / \mathrm{s}\right)$

degrees Centigrade $\left({ }^{\circ} \mathrm{C}\right)$
By

4,047
43,560
1,233
0.504
0.3048
1.609
0.02832
1.8

To obtatn

square meter $\left(\mathrm{m}^{2}\right)$

square foot $\left(f t^{2}\right)$

cubic meter $\left(\mathrm{m}^{3}\right)$

cublc foot per second per day [ $\left(\mathrm{ft}^{3 / \mathrm{s}}\right) /$ day $]$

meter (m)

kllometer $(\mathrm{km})$

cubic meter per second $\left(\mathrm{m}^{3} / \mathrm{s}\right)$

degrees Fahrenhe1t $\left({ }^{\circ} \mathrm{F}\right)$ (add $32^{\circ} \mathrm{F}$ to converted value) 


\title{
An Assessment of Streamflow, Water Quality, and the Effects of Constructing an Impoundment on Bridge Creek at Augusta, Wisconsin
}

\author{
by Leo B. House
}

\begin{abstract}
This study documents streamflow, temperature, and water-quality conditions of Bridge Creek at Augusta, Wisconsin, and evaluates the potential effects of a proposed small impoundment on the creek. The effects are of concern to the Wisconsin Department of Natural Resources because the stream is a Class II trout stream.

Average daily streamflow, from records collected during the 1980 water year, was about 50 cubic feet per second, and flow ranged from 4.5 to 1,010 cubic feet per second. Average summer (1980) water temperature of the creek was $21.0^{\circ} \mathrm{C}$, and the average summer dissolved-oxygen concentration was $7.1 \mathrm{milligrams}$ per 11ter. Water temperature did not exceed $26.0^{\circ} \mathrm{C}$, and dissolved oxygen did not fall below 6.0 milligrams per liter at any time during the summer.

A computer-simulated average summer temperature below the proposed impoundment was $22.5^{\circ} \mathrm{C}$ with a surface-level outlet from the reservolr, and $21.9^{\circ} \mathrm{C}$ with a bottom-draw outlet. Dissolved oxygen exceeded 6.0 milligrams per liter in both cases.

Nutrient concentrations in Bridge Creek and comparisons with a similar impoundment at nearby Fa11 Creek indicate that the proposed impoundment would have nuisance weed growth. The impoundment would have a computed transit time of about 3 days, with a surface-level outlet, or 1 day with a bottom-draw outlet, assuming a normal pool elevation and a summer base flow of 7.5 cubic feet per second. Total storage in the proposed impoundment is estimated to be 48 acre-feet.
\end{abstract}




\section{INTRODUCTION}

This study was made by the U.S. Geological Survey (USGS) in cooperation with the Wisconsin Department of Natural Resources (DNR). Before 1955, Bridge Creek at Augusta, Wis., (fig. 1) had a small millpond dam that was washed out by a flood. Beginning in 1972, the city of Augusta has sought permission to build a 10-ft high dam that would re-create the impoundment. The proposed impoundment would have a surface area of 14 acres and a volume of 48 acre-ft.

Bridge Creek is a trout stream and effects on water quality of the proposed impoundment and any deleterious effects on the trout population are of concern. Water quality may also have an impact on recreational use of the completed impoundment pool.

This study was made to establish the current hydrologic and water-quality conditions of Bridge Creek at Augusta and to simulate conditions that would result from constructing the dam.

The hydrologic and water-quality conditions at the site of the proposed impoundment pool and a length of channel extending about 2 mi downstream from the proposed damsite were studied and simulated with computer models. The Fal1 Creek Pond, located $12 \mathrm{mi}$ northwest, was also sampled as an indicator of what the proposed impoundment could be like in a nutrient-enriched situation.

\section{METHOD OF STUDY}

A continuous-record gaging station was established at the proposed damsite on Bridge Creek at Augusta and flow was monitored for the 1980 water year. Stream temperature and DO (dissolved oxygen) were monitored for the same period at the upstream inflow point to the proposed impoundment. Do and temperature were also measured at various points downstream from the damsite during the summer of 1979 .

Water-quality samples were taken periodically from Bridge Creek to determine nutrient concentrations, total organic carbon, and biochemical oxygen demand values. Chemical analysis of water was made in accordance with USGS Techniques of Water Resources Investigations (1979).

Base-flow conditions of the Bridge Creek basin were determined by 18 discharge measurements throughout the basin ( 1.1 ). All these measurements were made within 2 days during the low-flow period of July 1980 .

The streamflow and water-quality data collected were used as inputs to computer models. Water temperature and dissolved-oxygen concentration in the proposed impoundment and in the channel downstream were simulated for postconstruction conditions.

\section{ACKNOWLEDGMENTS}

We wish to acknowledge the services of Linda Osborn and Lucille Granrose, our local observers for Bridge Creek at Augusta, Wis. 


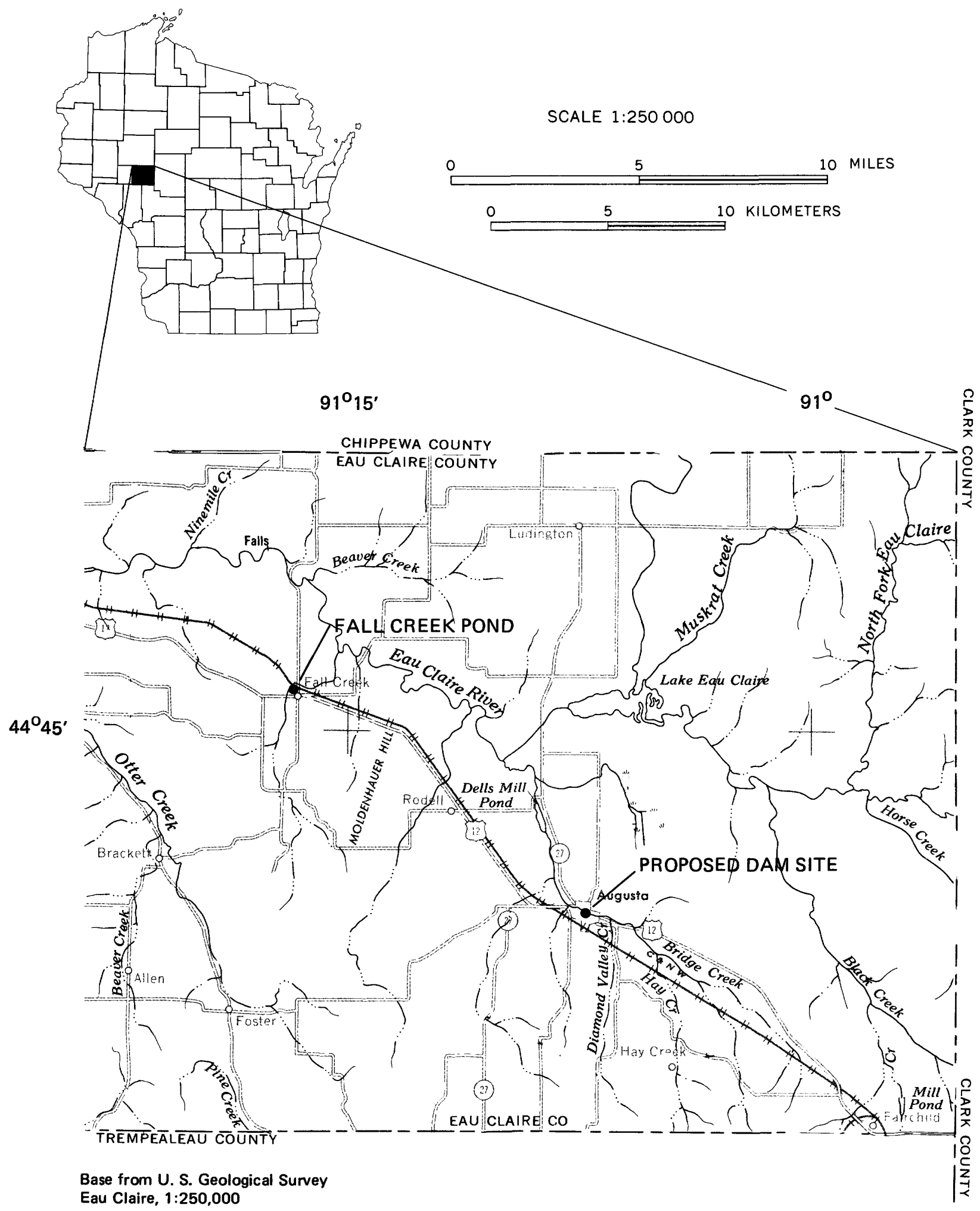

Figure 1. Location of Bridge Creek at Augusta, Wis. 
The city of Augusta assisted the project by allowing the construction of the equipment shelters on city property and making the laboratory facilities at the sewage-treatment plant available for water-quality analysis. Without these services, the study could not have been made as efficiently.

\section{DESCRIPTION OF THE BRIDGE CREEK BASIN}

The Bridge Creek basin is in southeastern Eau Claire County, with fringe areas extending south into Jackson County. The drainage areas of the basin at various locations along Bridge Creek are given in table 1 and are delineated on plate 1 .

The upper basin area (upstream from the gaging station) is of primary concern, as runoff from this area will affect the water quality of the proposed impoundment. This area is drained by the main stem of Bridge Creek and three tributaries; Diamond Valley, Hay, and Travis Creeks. Diamond Valley Creek drains a hilly farmland area, as does Hay Creek. Travis Creek and the main stem of Bridge Creek drain an area of mixed forest and tamarack swamps. Farming and urban development in the upper Bridge Creek watershed is less than that of other impoundment basins in the area, such as the one at Fal1 Creek (fig. 1).

Therefore, the nutrient runoff per acre of basin should be relatively lower for the Bridge Creek impoundment.

The maximum channel distance that direct runoff must flow is 9.85 mi from the most upstream point in the basin to the proposed damsite. In this distance, the channel drops $185 \mathrm{ft}$, for an average channel slope of $19 \mathrm{ft} / \mathrm{mi}$.

Table 1. Bridge Creek basin drainage areas

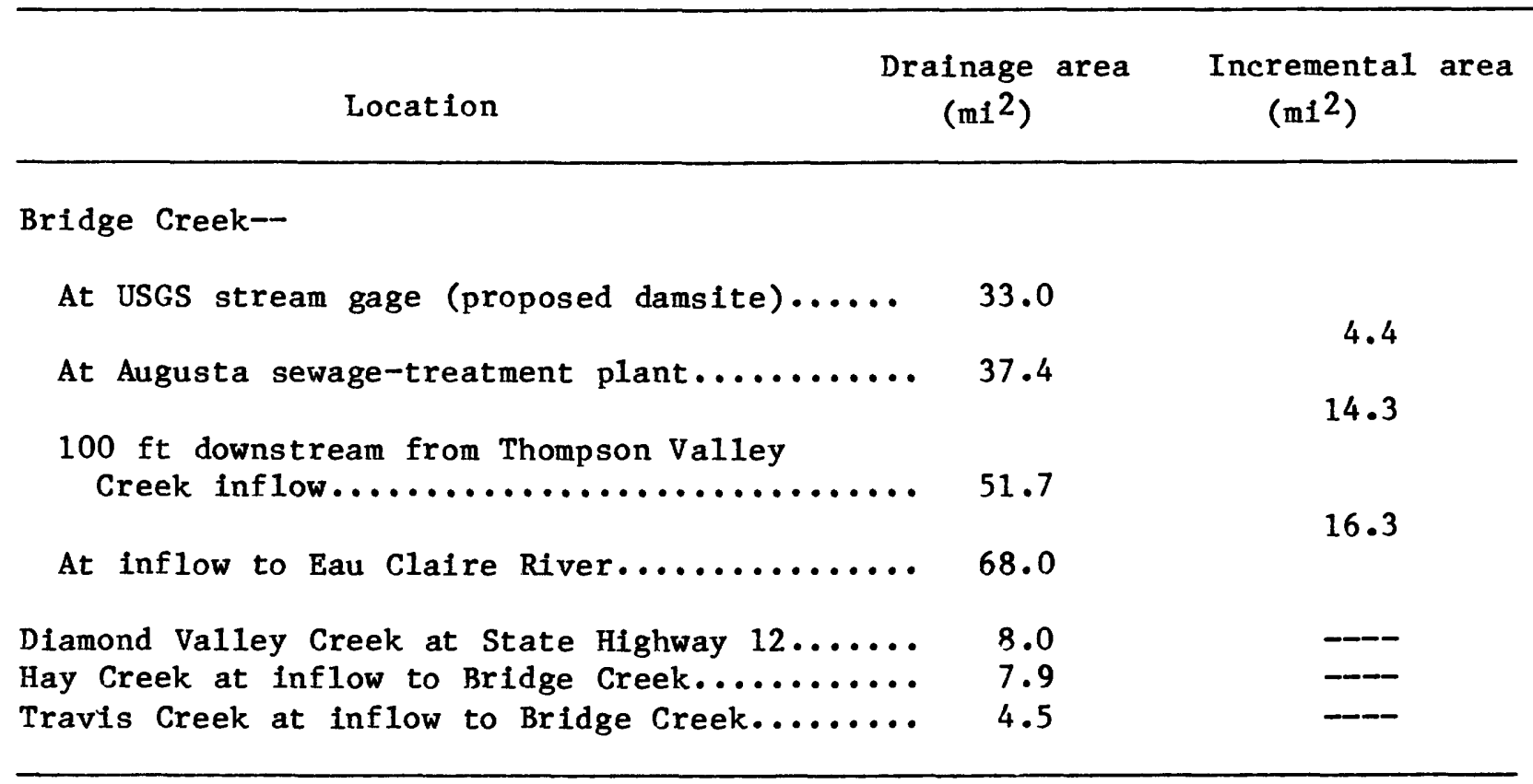




\section{STREAMFLOW CHARACTERISTICS OF BRIDGE CREEK}

\section{RECORDED STREAMFLOW DATA}

A USGS continuous-record gaging station (05366300) was established on Bridge Creek for the 1980 water year. The station was $150 \mathrm{ft}$ upstream from the County Highway G bridge in Augusta. The gage house was on the right bank next to the remains of the old millpond dam. The photo in figure 2 shows the remains of the old dam at the stream-gage site and also shows the proposed new damsite.

The average daily discharge, in cublc feet per second, is shown for each day of the 1980 water year in table 2. Monthly total, mean, maximum, and minimum daily discharges also are summarized.

The discharge records are considered poor from January 27 through March 15, 1980. During this period, the stage discharge was affected by ice and by equipment failures.

Discharge reached a maximum on September 21,1980 , with a daily average of $1,010 \mathrm{ft}^{3} / \mathrm{s}$; instantaneous maximum discharge was $1,450 \mathrm{ft}^{3} / \mathrm{s}$.

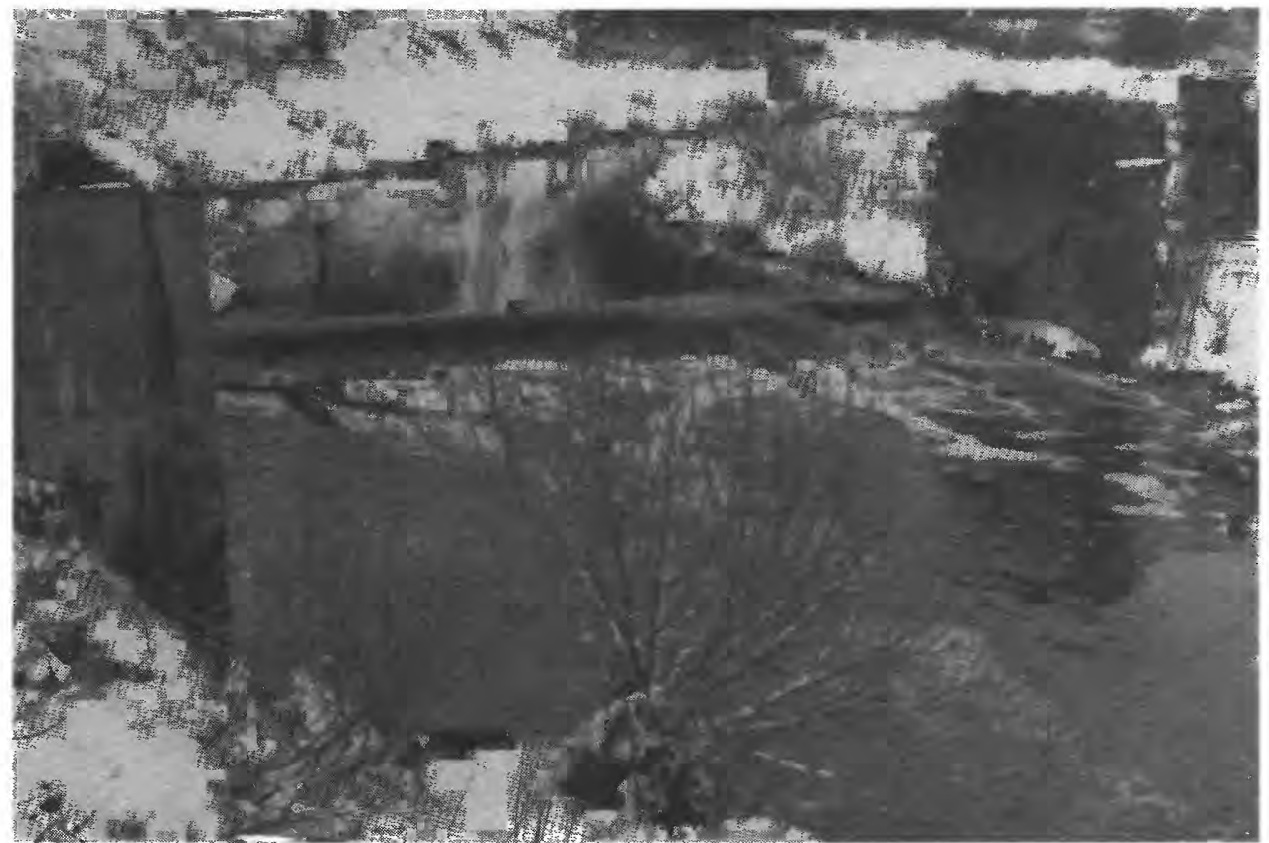

Figure 2. USGS stream gage and proposed dam site, Bridge Creek at Augusta, Wis., Spring 1980. 
Table 2. Daily discharge records for Bridge Creek at Augusta.

[Discharge, in cubic feet per second, water year October 1979 to September 1980]

\begin{tabular}{|c|c|c|c|c|c|c|c|c|c|c|c|c|}
\hline Day & Oct. & Nov. & Dec. & Jan. 1 & Feb. 1 & Mar. ${ }^{1}$ & Apr. & May & June & July & Aug. & Sept. \\
\hline $\begin{array}{l}1 \\
2\end{array}$ & $\begin{array}{l}27 \\
36\end{array}$ & $\begin{array}{l}47 \\
41\end{array}$ & $\begin{array}{l}17 \\
15\end{array}$ & $\begin{array}{l}12 \\
12\end{array}$ & $\begin{array}{l}5.3 \\
5.3\end{array}$ & $\begin{array}{l}4.4 \\
4.4\end{array}$ & $\begin{array}{l}48 \\
37\end{array}$ & $\begin{array}{l}21 \\
21\end{array}$ & $\begin{array}{l}51 \\
73\end{array}$ & $\begin{array}{l}15 \\
14\end{array}$ & $\begin{array}{l}7.2 \\
7.2\end{array}$ & $\begin{array}{l}69 \\
42\end{array}$ \\
\hline 3 & 20 & 32 & 15 & 12 & 5.3 & 4.4 & 40 & 20 & 50 & 12 & 7.4 & 29 \\
\hline 4 & 13 & 26 & 15 & 11 & 5.2 & 4.4 & 39 & 19 & 34 & 11 & 7.5 & 65 \\
\hline 5 & 13 & 43 & 15 & 11 & 5.2 & 4.4 & 118 & 19 & 117 & 11 & 8.0 & 66 \\
\hline 6 & 13 & 112 & 17 & 11 & 5.2 & 4.3 & 112 & 18 & 236 & 9.8 & 7.5 & 36 \\
\hline 7 & 13 & 95 & 19 & 11 & 5.1 & 4.3 & 92 & 17 & 211 & 8.9 & 32 & 24 \\
\hline 8 & 13 & 56 & 22 & 11 & 5.1 & 4.2 & 121 & 17 & 176 & 7.5 & 582 & 20 \\
\hline 9 & 13 & 37 & 16 & 11 & 5.0 & 4.2 & 141 & 16 & 92 & 7.5 & 436 & 37 \\
\hline 10 & 13 & 27 & 16 & 11 & 5.0 & 4.3 & 95 & 16 & 52 & 7.4 & 135 & 41 \\
\hline 11 & 15 & 23 & 18 & 19 & 5.0 & 4.5 & 71 & 22 & 39 & 7.3 & 56 & 28 \\
\hline 12 & 14 & 24 & 21 & 17 & 5.0 & 4.4 & 93 & 21 & 32 & 7.3 & 40 & 789 \\
\hline 13 & 13 & 24 & 13 & 14 & 4.9 & 4.2 & 75 & 21 & 29 & 7.2 & 20 & 541 \\
\hline 14 & 14 & 22 & 12 & 13 & 4.9 & 4.2 & 55 & 27 & 26 & 7.4 & 17 & 161 \\
\hline 15 & 13 & 22 & 12 & 20 & 4.9 & 4.5 & 51 & 21 & 21 & 7.5 & 15 & 82 \\
\hline 16 & 12 & 24 & 12 & 103 & 4.9 & 74 & 49 & 19 & 19 & 8.5 & 13 & 58 \\
\hline 17 & 12 & 28 & 12 & 160 & 4.9 & 223 & 46 & 17 & 20 & 7.9 & 20 & 43 \\
\hline 18 & 12 & 28 & 13 & 132 & 4.8 & 240 & 51 & 58 & 18 & 7.7 & 26 & 34 \\
\hline 19 & 26 & 28 & 13 & 80 & 4.8 & 301 & 55 & 82 & 36 & 7.6 & 22 & 40 \\
\hline 20 & 31 & 27 & 12 & 46 & 4.8 & 243 & 53 & 50 & 30 & 7.5 & 26 & 147 \\
\hline 21 & 23 & 29 & 12 & 32 & 6.0 & 156 & 51 & 26 & 22 & 7.4 & 54 & 1,010 \\
\hline 22 & 165 & 59 & 13 & 24 & 17 & 74 & 51 & 17 & 20 & 7.3 & 42 & 496 \\
\hline 23 & 341 & 65 & 25 & 18 & 14 & 22 & 62 & 16 & 18 & 7.4 & 21 & 155 \\
\hline 24 & 198 & 49 & 28 & 15 & 9.0 & 19 & 54 & 15 & 17 & 7.2 & 17 & 82 \\
\hline 25 & 91 & 37 & 18 & 11 & 6.7 & 34 & 46 & 15 & 16 & 7.4 & 16 & 73 \\
\hline 26 & 53 & 34 & 15 & 8.0 & 5.0 & 74 & 39 & 15 & 16 & 8.4 & 21 & 72 \\
\hline 27 & 41 & 33 & 14 & 6.3 & 4.7 & 77 & 35 & 16 & 15 & 7.7 & 24 & 62 \\
\hline 28 & 36 & 27 & 13 & 5.9 & 4.6 & 56 & 30 & 16 & 17 & 7.4 & 66 & 55 \\
\hline 29 & 32 & 25 & 13 & 5.6 & 4.5 & 48 & 26 & 19 & 16 & 7.4 & 43 & 49 \\
\hline 30 & 28 & 27 & 14 & 5.5 & $-\infty$ & 56 & 24 & 46 & 16 & 7.3 & 65 & 45 \\
\hline 31 & 32 & - & 12 & 5.4 & -- & 57 & $-\infty$ & 72 & - & 7.4 & 91 & - \\
\hline Total & 1,376 & 1,151 & 482 & 853.7 & 172.1 & $1,819.1$ & 1,860 & 795 & 1,535 & 262.3 & $1,982.8$ & 4,451 \\
\hline Mean & 44.4 & 38.4 & 15.5 & 27.5 & 5.93 & 58.7 & 62.0 & 25.6 & 51.2 & 8.46 & 64.0 & 148 \\
\hline Maximum & 341 & 112 & 28 & 160 & 17 & 301 & 141 & 82 & 236 & 15 & 582 & 1,010 \\
\hline Minimum & 12 & 22 & 12 & 5.4 & 4.5 & 4.2 & 24 & 15 & 15 & 7.2 & 7.2 & 20 \\
\hline Water ye & ar 1980 & Total & $-16,7$ & 40.0 & Mean - & -45.7 & Maximum & $-1,010$ & Minim & $u m-4.2$ & & \\
\hline
\end{tabular}

${ }^{1}$ Records from January 27 through March 15 are estimated. 


\section{BASE-FL.OW MEASUREMENTS}

A discharge measurement was made at the sites indicated on plate 1 during July 9 and 10, 1980; results are 1isted in table 3. These measurements were made during the summer's lowest flow period and represent ground-water inflow to the stream, or base-flow conditions.

An analysis of these measurements shows that the reach upstream from Site No. 7 to Sites No. 4 and 5 seems to be a losing reach. The total flow of Site No. 4 plus Site No. 5 equals $1.59 \mathrm{ft}^{3} / \mathrm{s}$, but the measured flow at downstream Site No. 7 is only $1.08 \mathrm{ft}^{3} / \mathrm{s}$. This may be due to evapotranspiration from the swamp vegetation in the intervening reaches.

Site No. 10 may be dry due to a small dam upstream on the unnamed tributary.

The increase in discharge between Sites No. 12 and 13 on the unnamed "cannery trib" is due to the inflow of effluent from the canning factory in Augusta. This difference implies a $1.22 \mathrm{ft}^{3} / \mathrm{s}$ inflow from the cannery.

Table 3. Bridge Creek basin base-flow measurements, July 9 and 10, 1980

(Refer to plate 1)

\begin{tabular}{|c|c|c|}
\hline Site no. & Description & $\begin{array}{l}\text { scharge } \\
\left(\mathrm{ft}^{3} / \mathrm{s}\right)\end{array}$ \\
\hline 1 & Most upstream site on Bridge Creek................ & 0.69 \\
\hline 2 & Unnamed Bridge Creek tributary................. & .10 \\
\hline 3 & Bridge Creek upstream from Cranberry Bog........... Not & accessible \\
\hline 4 & 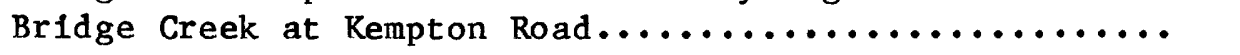 & .82 \\
\hline 5 & Travis Creek at Kempton Road................... & .77 \\
\hline 6 & Unnamed Bridge Creek tributary at Warner Road.......... & .0 (dry) \\
\hline 7 & 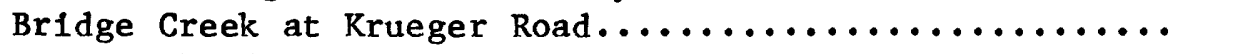 & 1.08 \\
\hline 8 & 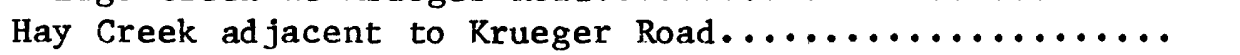 & 1.99 \\
\hline 9 & Bridge Creek just upstream from U.S. Highway $12 \ldots \ldots \ldots$ & 4.06 \\
\hline 10 & Unnamed Bridge Creek tributary adjacent to & \\
\hline 11 & 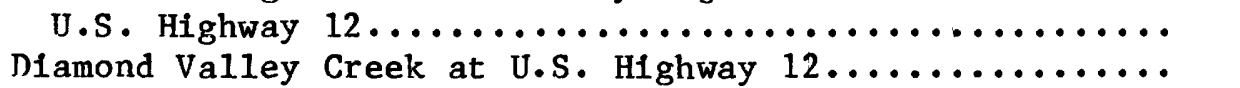 & $2.0(\mathrm{dry})$ \\
\hline GAGE $^{1}$ & USGS stream-gage site on Bridge Creek.............. & 7.55 \\
\hline 12 & Unnamed "cannery trib" at Stintson Road....... & .10 \\
\hline 13 & Unnamed "cannery trib" downstream from & \\
\hline & 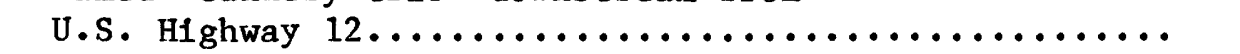 & 1.32 \\
\hline $\begin{array}{l}\text { STP } \\
14\end{array}$ & 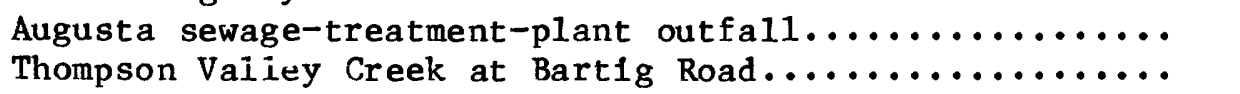 & $\begin{array}{r}.48 \\
4.23\end{array}$ \\
\hline 16 & Bridge Creek at County Highway $v \ldots \ldots \ldots \ldots \ldots \ldots \ldots$ & 15.1 \\
\hline 17 & Browns Creek at State Highway $27 \ldots \ldots \ldots \ldots \ldots \ldots \ldots$ & 1.18 \\
\hline 18 & Bridge Creek at mouth with Eau Claire River........... & 18.7 \\
\hline
\end{tabular}

${ }^{1}$ This is also the proposed damsite and USGS stream-gage site. 


\section{LOW-FLOW CHARACTERISTICS}

The low-flow characteristics for Bridge Creek at the Augusta sewagetreatment plant, which is 4,000 $\mathrm{ft}$ downstream from the damsite, have previously been estimated by the U.S. Geological Survey (Holmstrom, 1979). The estimate of the $Q 7,2$ was $4.2 \mathrm{ft}^{3} / \mathrm{s}$ and $Q 7,10$ was $2.6 \mathrm{ft}^{3} / \mathrm{s}$. The annual 7-day low flow will be less than the $Q 7,2$ at intervals averaging 2 years and less than the $Q 7,10$ at intervals averaging 10 years. The sewage-treatment plant is $4,000 \mathrm{ft}$ downstream from the proposed damsite. The $Q 7,2$ and $Q 7,10$ estimates are considered reasonable estimates for the damsite under present conditions since no inflowing tributaries intervene.

Note that the $Q 7,2$ and $Q 7,10$ estimates do not include effluent from the sewage-treatment plant or the cannery outfall nearby.

The lowest weekly summer flow period recorded for Bridge Creek during the study had an average discharge of $7.3 \mathrm{ft}^{3} / \mathrm{s}$. This occurred from July 29 through August 4, 1980. However, the lowest flows may have occurred during February. Reliable flow data are not available for the winter period due to problems with ice, but flows less than $6.0 \mathrm{ft}^{3} / \mathrm{s}$ were common.

\section{WATER-QUALITY DATA FOR BRIDGE CREEK}

The water quality of Bridge Creek was monitored by several methods at a site (station number 05366290) located at the inflow point to the proposed impoundment. During the critical low-flow period of July 8 through August 7, the DO and water temperature of Bridge Creek was monitored continuously at the waterquality site. A dissolved-oxygen probe with a continuous strip chart recorder was used for this purpose. The monitoring unit was inspected, serviced, and recalibrated weekly by the local observers. These data were used as input to the computer-simulation model to predict effects of the proposed impoundment. A summary of these data is given in table 4 .

The warmest daily average water temperature recorded was $24.0^{\circ} \mathrm{C}$ on $\mathrm{July} 10$, and the maximum peak temperature of $26.0^{\circ} \mathrm{C}$ was recorded July 12 .

The average daily temperature range was about $5^{\circ} \mathrm{C}$ between a day's maximum and minimum water temperatures. A day's coolest water temperature was usually at dawn; and the warmest temperature was in midafternoon.

The lowest daily average value of DO recorded was $6.4 \mathrm{mg} / \mathrm{L}$ (milligrams per 1iter) on July 8; the minimum for that day was $6.0 \mathrm{mg} / \mathrm{L}$. At no time did Do in Bridge Creek fall below $6.0 \mathrm{mg} / \mathrm{L}$ at the water-quality site during the July 8 through August 7 period.

The average daily Do range was $1.3 \mathrm{mg} / \mathrm{L}$ between the maximum and minimum. DO was usually lowest at dawn and highest in midafternoon. Apparently, photosynthesis in the stream increased the DO during the day, and respiratory demands by aquatic organisms decreased the DO at night. Without photosynthetic and respiration effects, one would have expected the DO to drop during the day, as the water temperature increased. 
Table 4. Summary of the continuous DO and water-temperature data for Bridge Creek at Augusta, station no. 05366290

\begin{tabular}{|c|c|c|c|c|c|c|c|c|}
\hline Date & \multirow{2}{*}{$\frac{\begin{array}{c}\text { Average water } \\
\text { temperature } \\
\left({ }^{\circ} \mathrm{C}\right)\end{array}}{22.0}$} & \multirow{2}{*}{$\begin{array}{c}\begin{array}{c}\text { Maximum water } \\
\text { temperature } \\
\left({ }^{\circ} \mathrm{C}\right)\end{array} \\
24.0\end{array}$} & \multirow{2}{*}{$\frac{\begin{array}{c}\text { Minimum water } \\
\text { temperature } \\
\left({ }^{\circ} \mathrm{C}\right)\end{array}}{19.0}$} & \multirow{2}{*}{$\frac{\begin{array}{c}\text { Maximum- } \\
\text { minimum } \\
\left({ }^{\circ} \mathrm{C}\right)\end{array}}{5.0}$} & \multirow{2}{*}{$\frac{\begin{array}{c}\text { Average DO } \\
(\mathrm{mg} / \mathrm{L})\end{array}}{6.4}$} & \multirow{2}{*}{$\frac{\begin{array}{c}\text { Maximum DO } \\
(\mathrm{mg} / \mathrm{L})\end{array}}{6.6}$} & \multirow{2}{*}{$\frac{\begin{array}{c}\text { Minimum } \\
(\mathrm{mg} / \mathrm{L})\end{array}}{6.0}$} & \multirow{2}{*}{$\frac{\begin{array}{c}\text { Maximum- } \\
\text { minimum } \\
(\mathrm{mg} / \mathrm{L})\end{array}}{0.6}$} \\
\hline July & & & & & & & & \\
\hline July & 22.5 & 25.0 & 19.0 & 6.0 & 7.5 & 8.3 & 6.7 & 1.6 \\
\hline July 1 & 24.0 & 25.5 & 19.5 & 6.0 & 7.4 & 7.9 & 6.3 & 1.6 \\
\hline July 1 & 23.0 & 25.0 & 21.0 & 4.0 & 7.0 & 7.6 & 6.0 & 1.6 \\
\hline July 1 & 23.5 & 26.0 & 21.0 & 5.0 & 6.8 & 7.5 & 6.2 & 1.3 \\
\hline July 1 & 21.5 & 23.0 & 19.0 & 4.0 & 7.2 & 7.8 & 6.6 & 1.2 \\
\hline July 1 & 22.0 & 24.0 & 21.0 & 3.0 & 7.0 & 7.6 & 6.1 & 1.5 \\
\hline July 1 & 23.0 & 25.5 & 20.5 & 5.0 & 6.8 & 7.4 & 6.1 & 1.3 \\
\hline July 1 & 22.0 & 24.5 & 20.0 & 4.5 & 6.7 & 7.2 & 6.2 & 1.0 \\
\hline July 1 & 22.0 & 25.0 & 19.0 & 6.0 & 6.9 & 7.3 & 6.2 & 1.1 \\
\hline July 1 & 21.5 & 23.5 & 20.0 & 3.5 & $7.0(E)$ & (E) & (E) & -- \\
\hline July 1 & 21.5 & 24.5 & 19.0 & 5.5 & $7.0(\mathrm{E})$ & (E) & (E) & -- \\
\hline July 2 & 21.5 & 22.5 & 20.0 & 2.5 & $7.0(\mathrm{E})$ & (E) & (E) & - \\
\hline July 2 & 21.0 & 23.5 & 18.0 & 5.5 & $7.0(\mathrm{E})$ & (E) & (E) & -- \\
\hline July 2 & 20.0 & 22.0 & 18.0 & 4.0 & 7.0 & 7.4 & 6.5 & .9 \\
\hline Ju1y 2 & 19.0 & 22.0 & 15.5 & 6.5 & 6.9 & 7.7 & 5.0 & 1.7 \\
\hline July 2 & 20.0 & 24.5 & 16.5 & 8.0 & 7.1 & 7.3 & 6.0 & 1.3 \\
\hline July 2 & 20.5 & 21.0 & 19.5 & 1.5 & 7.1 (E) & (E) & (E) & - \\
\hline July 2 & 19.5 & 22.0 & 17.0 & 5.0 & $7.2(\mathrm{E})$ & (E) & (E) & -- \\
\hline July 2 & 19.0 & 22.0 & 15.5 & 6.5 & $7.3(\mathrm{E})$ & (E) & (E) & - \\
\hline July 2 & 19.5 & 21.5 & 17.5 & 4.0 & $7.2(\mathrm{E})$ & (E) & (E) & -- \\
\hline July 2 & 20.0 & 23.5 & 17.5 & 6.0 & $7.4(E)$ & (E) & (E) & -- \\
\hline July 3 & 20.0 & 22.0 & 17.5 & 4.5 & 7.5 & 8.4 & 6.8 & 1.6 \\
\hline July 3 & 21.0 & 24.0 & 18.5 & 5.5 & 7.4 & 8.1 & 7.2 & .9 \\
\hline Aug. & 21.0 & 24.0 & 18.5 & 5.5 & 7.3 & 8.0 & 6.6 & 1.4 \\
\hline Aug. & 20.5 & 22.0 & 19.0 & 3.0 & 7.2 & 8.0 & 6.6 & 1.4 \\
\hline Aug. & 20.0 & 23.0 & 17.0 & 6.0 & 7.1 & 7.6 & 6.2 & 1.4 \\
\hline Aug. & 19.5 & 20.5 & 19.0 & 1.5 & 6.7 & 7.2 & 6.2 & 1.0 \\
\hline Aug. & 19.5 & 22.5 & 17.0 & 5.5 & 6.9 & 7.5 & 6.4 & 1.1 \\
\hline Aug. & 19.0 & 23.0 & 17.0 & 6.0 & 7.0 & 7.6 & 6.4 & 1.2 \\
\hline Aug. & 20.5 & 22.0 & 19.0 & 3.0 & 6.9 & 7.5 & 6.5 & 1.0 \\
\hline AVERAG & 21.0 & 23.3 & 18.6 & 4.75 & 7.1 & 7.6 & 6.4 & 1.3 \\
\hline
\end{tabular}

(E) Do values were estimated when the recorder probe failed. Estimated values are based on plot trends and water temperature.

In addition, water-temperature, DO, and 5-day biochemical oxygen demand $\left(B_{5}\right)$ data were collected weekly by two local observers during the open-water period of 1980 . These data are presented in table 5. Water temperature was measured with a mercury thermometer, and DO was determined by a modified Winkler titration method. $\mathrm{All} \mathrm{BOD}_{5}$ samples were incubated at $20^{\circ} \mathrm{C}$ in the city of Augusta's unit at the sewage-treatment plant. The visible water quality of the stream was good, but it had a slight stale odor during the warm months of July and August 1980.

Water-quality data were also collected by USGS personnel periodically. These data are also presented in table 5.

Water-quality data were collected through August 1980. 
Table 5. Periodic observations of water temperature, DO, and $\mathrm{BOD}_{5}$

\begin{tabular}{|c|c|c|c|c|c|c|}
\hline \multicolumn{2}{|l|}{ Date } & \multirow{2}{*}{$\begin{array}{c}\begin{array}{c}\text { Time } \\
\text { (hours) }\end{array} \\
1500\end{array}$} & \multirow{2}{*}{$\begin{array}{c}\begin{array}{c}\text { Water } \\
\text { temperature } \\
\left({ }^{\circ} \mathrm{C}\right)\end{array} \\
0.0\end{array}$} & \multirow{2}{*}{$\begin{array}{c}\begin{array}{c}\mathrm{DO} \\
(\mathrm{mg} / \mathrm{L})\end{array} \\
11.6\end{array}$} & \multirow{2}{*}{$\begin{array}{c}\begin{array}{c}\mathrm{BOD}_{5} \\
(\mathrm{mg} / \mathrm{L})\end{array} \\
---\end{array}$} & Remarks ${ }^{1}$ \\
\hline Mar. & 6 & & & & & Nutrient sample taken, USGS \\
\hline Mar. & 7 & 1020 & .0 & 10.1 & $-\infty$ & $21 / 2$ ft ice cover, USGS \\
\hline Mar. & 14 & 1550 & - & --- & 6.4 & \\
\hline Mar. & 22 & 1500 & 2.5 & 11.6 & -- & Flow over ice cover, USGS visit \\
\hline Mar. & 26 & 1530 & 5.0 & 13.2 & $\geq 8.8$ & Snowmelt runoff \\
\hline Apr. & 2 & 1320 & 10.0 & 12.0 & 2.0 & \\
\hline Apr. & 9 & 1500 & 1.0 & 12.0 & 3.6 & USGS visit April 9 and 10 \\
\hline Apr. & 10 & 0800 & 1.0 & 12.0 & -- & $\mathrm{pH}=6.6$, nutrient samples \\
\hline Apr. & 16 & 1530 & 8.0 & 10.2 & 2.2 & \\
\hline Apr. & 23 & 1530 & 15.0 & 9.2 & 2.2 & \\
\hline Apr & 30 & 1530 & 12.0 & 10.0 & 1.7 & \\
\hline May & 7 & 1530 & 11.0 & 10.0 & 2.2 & \\
\hline May & 14 & 1530 & 13.0 & 10.4 & 2.2 & \\
\hline May & 22 & 1530 & 21.0 & 8.0 & 2.0 & \\
\hline May & 28 & 1530 & 24.0 & 7.8 & 2.8 & \\
\hline June & 4 & 1600 & 19.0 & --- & 3.0 & DO lab analysis error \\
\hline June & 11 & 1500 & 18.0 & 8.0 & 1.1 & \\
\hline June & 18 & 1515 & 18.0 & 8.0 & 2.1 & \\
\hline June & 25 & 1530 & 24.0 & 7.6 & 2.0 & \\
\hline Ju1y & 2 & 1515 & 21.0 & 7.8 & 1.5 & \\
\hline July & 8 & 1745 & 23.9 & 6.9 & -- & $\begin{array}{l}\mathrm{pH}=7.0 \text {, specific conductance } \\
79 \text {, USGS }\end{array}$ \\
\hline
\end{tabular}


Table 5. Periodic observations of water temperature, $\mathrm{DO}$, and $\mathrm{BOD}_{5}-$ Continued

\begin{tabular}{|c|c|c|c|c|c|}
\hline Date & $\begin{array}{l}\text { Time } \\
\text { (hours) }\end{array}$ & $\begin{array}{l}\text { Water } \\
\text { temperature }\end{array}$ & $\begin{array}{c}\text { DO } \\
(\mathrm{mg} / \mathrm{L})\end{array}$ & $\begin{array}{l}\mathrm{BOD}_{5} \\
\mathrm{mg} / \mathrm{L})\end{array}$ & Remarks $^{1}$ \\
\hline July 9 & 0900 & 19.2 & 6.7 & $-\infty$ & $\begin{array}{l}\mathrm{pH}=7.0 \text {, specific conductance }= \\
82 \text {, USGS }\end{array}$ \\
\hline July 9 & 1300 & 22.8 & 6.9 & --- & USGS ran temp/DO/BOD5 profiles \\
\hline July 9 & 1550 & 25.0 & 7.4 & 1.6 & USGS took water-chemistry samples \\
\hline July 10 & 0900 & 19.0 & 7.7 & -- & USGS sampled Fall Creek \\
\hline July 16 & 1530 & 24.0 & 7.0 & 2.0 & \\
\hline July 23 & 1550 & 21.0 & 7.8 & 1.4 & \\
\hline July 30 & 1530 & 22.0 & 8.2 & 1.7 & \\
\hline Aug. 6 & 1530 & 23.0 & 8.0 & 1.2 & \\
\hline Aug. 13 & 1530 & 19.0 & 7.2 & .8 & \\
\hline Aug. 20 & 1600 & 22.3 & 7.5 & 2.2 & $\begin{array}{l}\mathrm{pH}=5.4, \text { specific conductance }= \\
67 \text {, USGS }\end{array}$ \\
\hline Aug. 25 & 1530 & 23.0 & 6.2 & -- & \\
\hline Aug. 26 & 1500 & 19.0 & 7.5 & -- & USGS \\
\hline Aug • 27 & 0845 & 18.0 & 8.1 & -- & USGS ran temp/DO/BOD 5 profile \\
\hline Aug . 28 & 1530 & 19.0 & 7.0 & 5.5 & Storm runoff \\
\hline
\end{tabular}

${ }^{1}$ USGS $=$ visit and data.

STREAM TEMPERATURE, DO, AND BOD 5 PROFILES

On July 9 and August 27 measurements of water temperature, DO, and BOD 5 were made at sites located downstream from the Bridge Creek water-quality monitoring site. This was done to establish existing conditions of Bridge Creek and its tributaries. The measurement sites are shown in figure 3 . A description of the sites follows: 
Site A.--This site is the water quality ( $Q W$ ) monitoring station, station number 05366290. It is located at the upstream end of the proposed impoundment, 2,400 ft upstream from the proposed damsite (channel distance).

Site B.-This site is the proposed damsite located $100 \mathrm{ft}$ upstream from the County Highway $\mathrm{G}$ bridge. It is also the USGS gaging station, number 05366300 . The sill from the old dam causes a free fall to the water surface downstream at low flows.

Site C.--This is the site of an abandoned dam located 2,800 ft downstream from Site $B$, and $200 \mathrm{ft}$ upstream from the State Highway 27 bridge. The sill from the old dam causes a free-fall cascade to the water surface downstream at low flows. (Site shown on cover of this report.)

Site D.--Inflow from an unnamed tributary enters Bridge Creek at this site, located $1,000 \mathrm{ft}$ downstream from Site $C$. The tributary, not Bridge Creek, was sampled. A cannery discharges its effluent to this tributary during periods of operation.

Site E.--Effluent from the city of Augusta sewage-treatment plant enters Bridge Creek at this point. The outfall is located about $50 \mathrm{ft}$ downstream from the cannery tributary inflow site. The sewage-treatment-plant effluent, not Bridge Creek, was sampled at this point.

Site F.--This site is located $1,100 \mathrm{ft}$ downstream from Site $\mathrm{C}$, and is $50 \mathrm{ft}$ downstream from the sewage-treatment-plant outfall site. The stream is only $15 \mathrm{ft}$ wide at this site during low flows.

Site G.--This site is located $50 \mathrm{ft}$ upstream from the inflow of Thompson Valley Creek and is located 6,500 ft downstream from Site $F$.

Site H.--Thompson Valley Creek enters Bridge Creek $50 \mathrm{ft}$ downstream from Site G. The tributary was sampled $30 \mathrm{ft}$ upstream from the junction.

The distance downstream from the water-quality site is summarized for various locations below. See figure 3 for reference.

\begin{tabular}{|c|c|c|}
\hline te & Description & \\
\hline A & QW Site--Reference Point.......... & $0 \mathrm{ft}$ \\
\hline B & Proposed damsite and USGS stream gage....... & $2,400 \mathrm{ft}$ \\
\hline C & 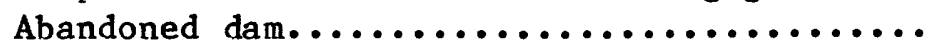 & $5,200 \mathrm{ft}$ \\
\hline D & Cannery tributary inflow site............ & $6,200 \mathrm{ft}$ \\
\hline $\mathrm{E}$ & Augusta sewage-treatment-plant outfall..... & $6,250 \mathrm{ft}$ \\
\hline $\mathbf{F}$ & $\begin{array}{l}50 \mathrm{ft} \text { downstream from sewage-treatment- } \\
\text { plant outfall } \ldots \ldots \ldots \ldots \ldots \ldots \ldots \ldots \ldots \ldots\end{array}$ & $6,300 \mathrm{ft}$ \\
\hline G & 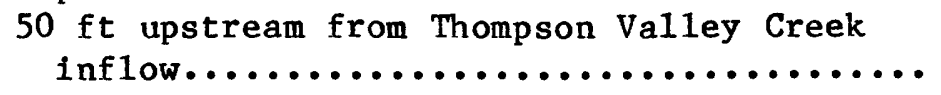 & $t$ \\
\hline $\mathrm{H}$ & Thompson Valley Creek inflow............. & 12,850 \\
\hline
\end{tabular}




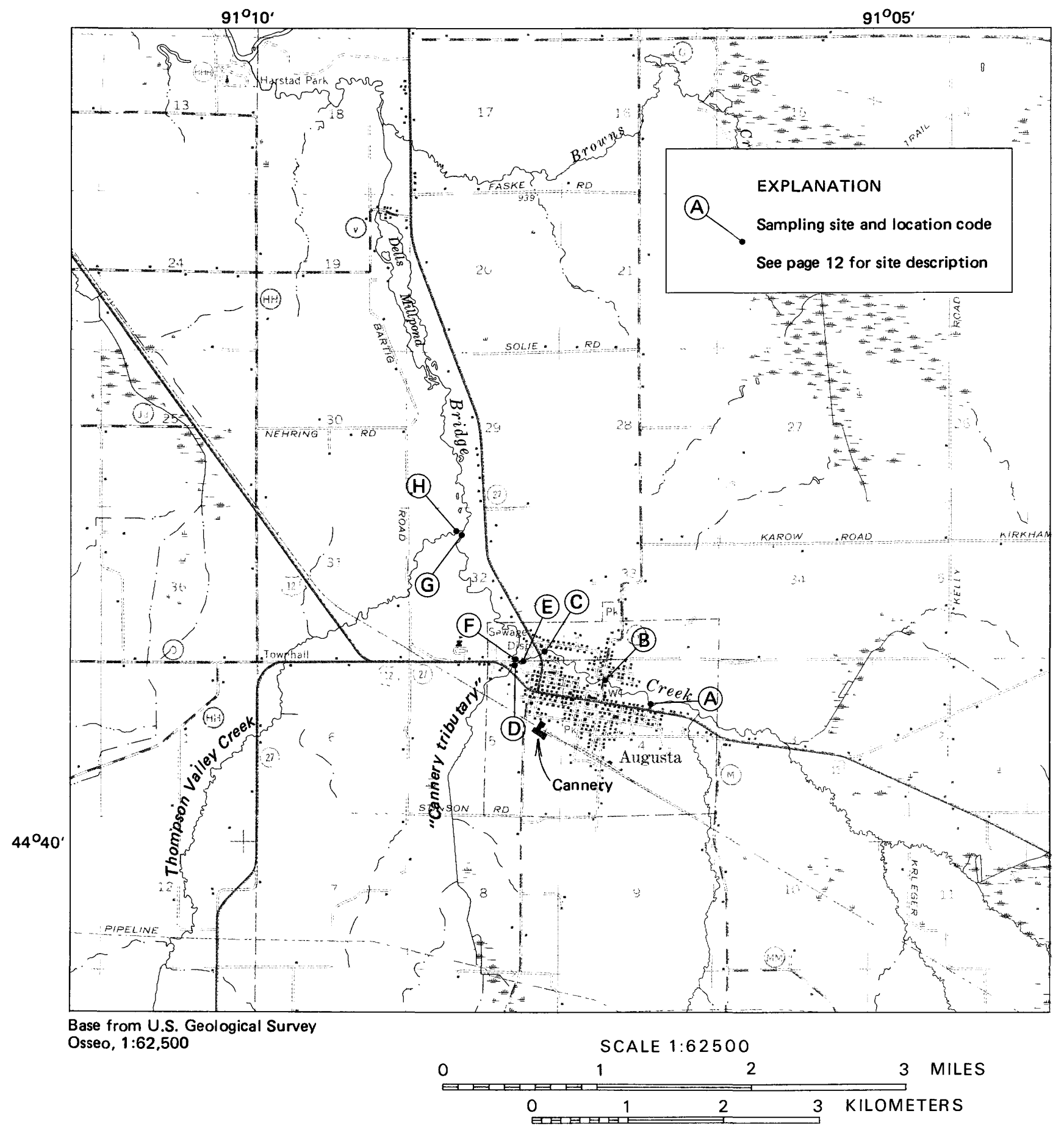

Figure 3. Stream temperature and dissolved-oxygen profile sites. 


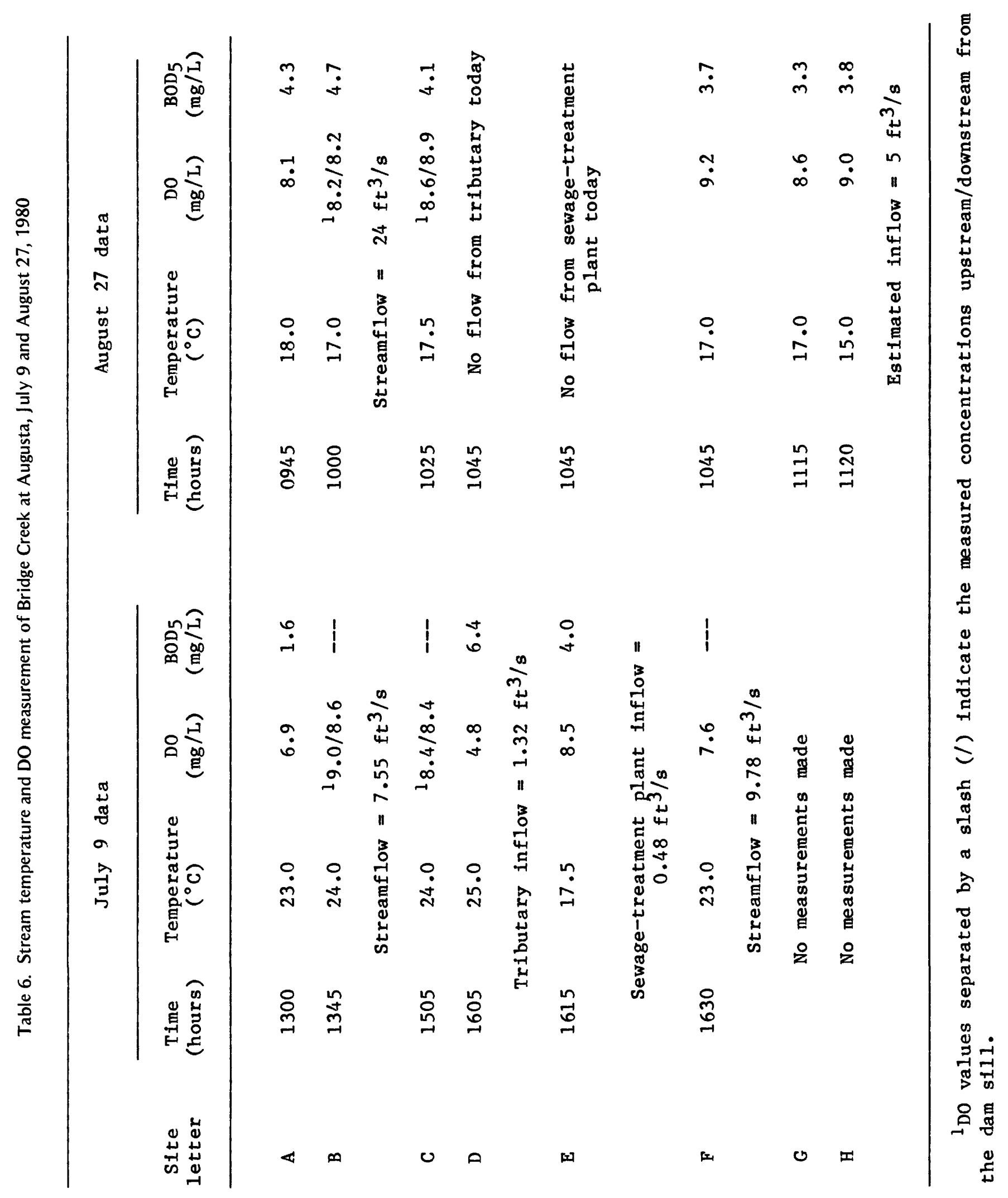


The stream temperature, $\mathrm{DO}$, and $\mathrm{BOD}_{5}$ data collected at each site are shown in table 6 .

On July 9, 1980, the streamflow averaged $7.5 \mathrm{ft} / \mathrm{s}$ at the gaging station (Site $B$ ). The peak water temperature recorded at the water-quality monitoring station (Site A) was $25^{\circ} \mathrm{C}$ at 1730 hours $(5: 30 \mathrm{p} \cdot \mathrm{m} \cdot)$. The $1.0^{\circ} \mathrm{C}$ increase in water temperature from Site A to Site B is probably due to solar heating between the hour of 1300 and 1345 . The $0.5^{\circ} \mathrm{C}$ decrease in temperature between Sites $\mathrm{C}$ and $F$ is probably due to shaded stream conditions and the cooling effects of the sewage-treatment-plant inflow.

The lowest DO recorded at Site A on July 9, 1980, was $6.7 \mathrm{mg} / \mathrm{L}$ at 2300 hours $(11: 00 \mathrm{p} \cdot \mathrm{m} \cdot)$. The measured dissolved oxygen at the profile sites was always greater than this value, probably due to photosynthetic algae activity during the daylight hours. This activity apparently lead to a DO supersaturated condition of $9.0 \mathrm{mg} / \mathrm{L}$ upstream from Site B.

Few $\mathrm{BOD}_{5}$ samples were taken on July 9, but it is clear that the BOD concentration of the cannery tributary inflow and the sewage-treatment plant were several times greater than Bridge Creek's background condition.

On August 27, 1980, the streamflow averaged about $24 \mathrm{ft}^{3} / \mathrm{s}$ at the gaging station. The temperature and DO recorder was no longer functioning, so average and extreme temperature and DO values are not known.

The DO on August 27 was greater than $8.0 \mathrm{mg} / \mathrm{L}$ at all sites measured. Some aeration was observed to occur at Site $C$ as the water cascaded over the old spillway and increased the DO concentration by $0.3 \mathrm{mg} / \mathrm{L}$.

BOD $_{5}$ samples were taken at each site for this profile. BOD $_{5}$ was observed to increase from 4.3 to $4.7 \mathrm{mg} / \mathrm{L}$ between Site $A$ and Site $B$. BOD 5 concentration was observed to decrease further downstream. This was probably due to dilution by inflow rather than due to oxidation of the BOD. There was no flow from the cannery tributary or the sewage-treatment-plant outfall.

\section{WATER-CHEMISTRY DATA FOR BRIDGE CREEK}

On March 5, 1980, water samples were taken from Bridge Creek at the gaging station (Site B) and analyzed for nutrients. Spring thaw and snowmelt runoff were not yet apparent in the stream. Flow was about $16 \mathrm{ft}^{3} / \mathrm{s}$. The results of this nutrient analysis are as follows:

Total nitrite $\left(\mathrm{NO}_{2}\right)+$ nitrate $\left(\mathrm{NO}_{3}\right)$ as nitrogen $=0.56 \mathrm{mg} / \mathrm{L}$ Phosphorus total as phosphorus $(P)=0.05 \mathrm{mg} / \mathrm{L}$

On Apri1 10, 1980, water samples were taken from Bridge Creek at the waterquality-monitoring station (Site $A$ ) and analyzed for nutrients. The discharge was about $100 \mathrm{ft}^{3} / \mathrm{s}$ due to runoff from snowmelt. The results of this more detailed nutrient analysis are as follows: 


$\begin{array}{ll}\text { Nitrogen total as } \mathrm{N} & =1.9 \mathrm{mg} / \mathrm{L} \\ \text { Total } \mathrm{NH}_{4}+0 \text { organic } \mathrm{N} \text { as } \mathrm{N} & =1.4 \mathrm{mg} / \mathrm{L} \\ \text { Dissolved } \mathrm{NO}_{2}+\mathrm{NO}_{3} \text { as } \mathrm{N} & =0.49 \mathrm{mg} / \mathrm{L} \\ \text { Phosphorus total as } \mathrm{P} & =0.08 \mathrm{mg} / \mathrm{L} \\ \text { Total organic carbon } & =16 \mathrm{mg} / \mathrm{L}\end{array}$

On July 9 water samples were taken from Bridge Creek at the water-quality monitoring station (Site A) for a complete water-chemistry analysis. The results of this analysis are shown in table 7 . These results should represent the summer base-flow water chemistry and do not reflect storm-runoff effects.

\section{DESCRIPTION OF PROPOSED IMPOUNDMENT}

The proposed impoundment resulting from the reconstruction of the dam would extend 2,400 ft upstream from the damsite and have an average width of $300 \mathrm{ft}$. The surface area of the pond would be 14 acres at normal pool elevation.

The average depth of the pond would be $3.3 \mathrm{ft}$ at the normal pool elevation. The maximum depth at normal pool elevation would be $8.5 \mathrm{ft}$ just upstream from the dam. The pond would be progressively shallower along its length upstream.

Table 7. Chemical analysis of water from Bridge Creek at Augusta, Wis.

[Analysis in milligrams per liter except fron and manganese, which are in micrograms per 11ter]

Date of collection--July 9, 1980

Streamflow, in cubic feet per second - 7.5

Specific conductance, in micromhos per centimeter $\left(\right.$ at $25^{\circ} \mathrm{C}$ )-- -25

$\mathrm{pH}$, units - 7.0

Water temperature, ${ }^{\circ} \mathrm{C}-\cdots 20.0$

Dissolved oxygen $\left(\mathrm{O}_{2}\right) \cdots \cdots$

Hardness, as $\mathrm{CaCO}_{3}-\cdots$

Noncarbonate hardness, as

$\mathrm{CaCO}_{3}-$

Calclum (Ca) - 7.4

Magnesium (Mg) -

Sodlum (Na) - 2.6

Potassium (K) - 2.8

Alkalinity, as $\mathrm{CaCO}_{3}$

Sulfate $\left(\mathrm{SO}_{4}\right)$

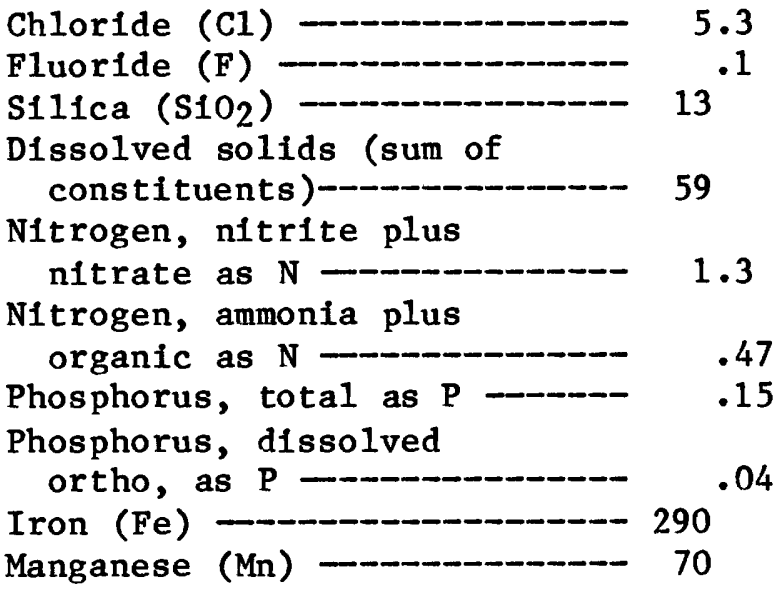

Chloride (C1)

59

.3 
The volume of the proposed impoundment would be 47.2 acre-ft at the normal pool elevation. The calculated flushing rate during the summer's low-flow period would be 3.1 days, assuming a base flow of $7.5 \mathrm{ft}^{3} / \mathrm{s}$. A flow of $23.6 \mathrm{ft}^{3} / \mathrm{s}$ would $\mathrm{fill}$ the impoundment in 1 day. During periods of higher flow the flushing rate would be accordingly less than 1 day.

The pool's surface area versus elevation curve is shown in figure 4. This curve was developed using a topographic map (Owen Ayres \& Associates, 1972) of the impoundment area. All elevations are referenced to a Railroad Commission of Wisconsin datum, Bronze Tablet No. 204. This local datum has an assigned elevation of $100 \mathrm{ft}$, with the normal pool surface at $92.5 \mathrm{ft}$ and the pool bottom at $84.0 \mathrm{ft}$.

The outlet from the impoundment could consist of a bottom-draw pipe sized to pass the normal base flow of about $7.5 \mathrm{ft} / \mathrm{s}$, coupled with a surface spillway to pass larger flows. The bottom-draw feature would help keep the released water temperatures cooler than if taken from the pool surface during summer.

\section{EFFECTS OF THE PROPOSED IMPOUNDMENT ON WATER QUALITY}

Several methods were used to predict the conditions that would exist in the proposed impoundment of Bridge Creek. One method was to look at conditions of an existing impoundment in the area.

The Fall Creek Pond at Fall Creek, Wis., is located about 12 mi northwest of Augusta (fig. 1). The pond has a surface area and depth configuration similar to the proposed Bridge Creek impoundment, although the drainage area (and inflow) is only about half that of Bridge Creek. More of the Fall Creek basin is in agricultural use than for Bridge Creek.

The Fall Creek Pond and its basin have been studied by the DNR as part of its Inland Lake Renewal Program. The primary problems in the impoundment are nuisance algae blooms and sedimentation that has greatly reduced the impoundment's depth.

The USGS collected nutrient data for the Fall Creek Pond during 1980. A summary of the USGS-collected data appears below. A comparison with the nutrient data collected for Bridge Creek shows that the Fall Creek values are several times larger.

April 10, 1980 - At inflow point to Fal1 Creek Pond, estimated streamflow = $14 \mathrm{ft}^{3} / \mathrm{s}$.

Nitrogen total as $\mathrm{N}=2.5 \mathrm{mg} / \mathrm{L}$ Nitrogen total as $\mathrm{NO}_{3}=11 \mathrm{mg} / \mathrm{L}$ Total $\mathrm{NH}_{4}$ + organic $\mathrm{N}=1.4 \mathrm{mg} / \mathrm{L}$ Dissolved $\mathrm{NO}_{2}+\mathrm{NO}_{3}$ as $\mathrm{N}=1.1 \mathrm{mg} / \mathrm{L}$
Phosphorus total as $\mathrm{P}=0.34 \mathrm{mg} / \mathrm{L}$ Phosphorus total as $\mathrm{PO}_{4}=1.0 \mathrm{mg} / \mathrm{L}$ Dissolved orthophosphate $=0.46 \mathrm{mg} / \mathrm{L}$ Dissolved orthophosphate as $P=0.15 \mathrm{mg} / \mathrm{L}$ 


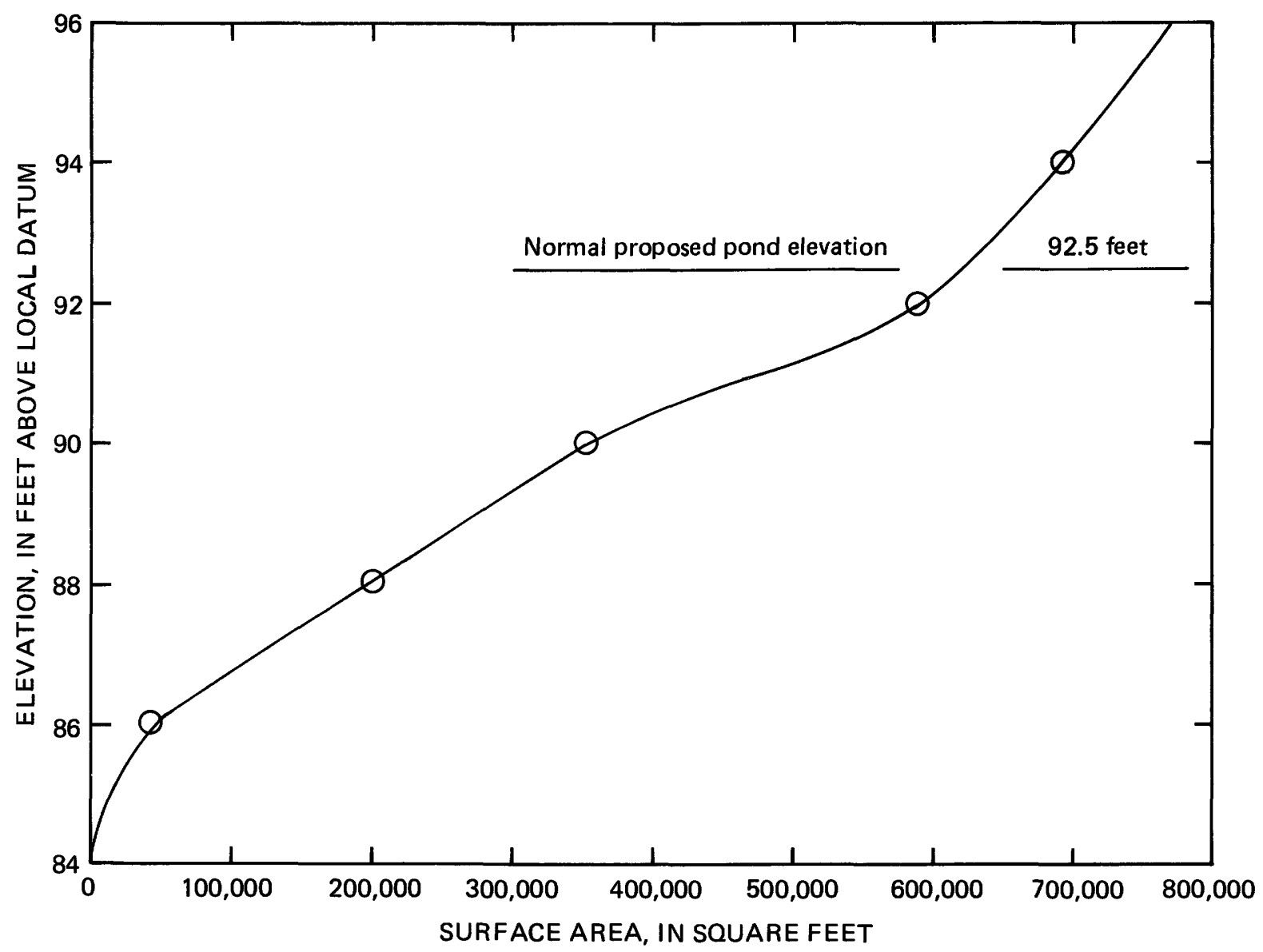

Figure 4. Surface area versus elevation curve for the proposed impoundment of Bridge Creek at Augusta, Wis.

July 10, 1980 - At inflow point to Fall Creek Pond, estimated streamflow = $1 \mathrm{ft}^{3} / \mathrm{s}$.

Nitrogen total as $N=1.6 \mathrm{mg} / \mathrm{L}$

Nitrogen total as $\mathrm{NO}_{3}=6.9 \mathrm{mg} / \mathrm{L}$

Phosphorus total as $P=0.35 \mathrm{mg} / \mathrm{L}$

Total $\mathrm{NH}_{4}$ + organic $\mathrm{N}=0.61 \mathrm{mg} / \mathrm{L}$

Phosphorus total as $\mathrm{PO}_{4}=1.1 \mathrm{mg} / \mathrm{L}$

Dissolved $\mathrm{NO}_{2}+\mathrm{NO}_{3}$ as $\mathrm{N}=0.96 \mathrm{mg} / \mathrm{L}$

Dissolved or thophosphate $=0.55 \mathrm{mg} / \mathrm{L}$

Dissolved orthophosphate as $\mathrm{P}=0.18 \mathrm{mg} / \mathrm{L}$

July 10, 1980 - 100 yards downstream of Fall Creek Pond outflow, measured streamf low $=2.9 \mathrm{ft}^{3} / \mathrm{s}$.

Nitrogen total as $\mathrm{N}=1.1 \mathrm{mg} / \mathrm{L}$ Nitrogen total as $\mathrm{NO}_{3}=5.0 \mathrm{mg} / \mathrm{L}$ Total $\mathrm{NH}_{4}+$ organic $\mathrm{N}=0.78 \mathrm{mg} / \mathrm{L}$

Dissolved $\mathrm{NO}_{2}+\mathrm{NO}_{3}$ as $\mathrm{N}=0.36 \mathrm{mg} / \mathrm{L}$
Phosphorus total as $P=0.23 \mathrm{mg} / \mathrm{L}$ Phosphorus total as $\mathrm{PO}_{4}=0.71 \mathrm{mg} / \mathrm{L}$ Dissolved orthophosphate $=0.28 \mathrm{mg} / \mathrm{L}$ Dissolved orthophosphate as $P=0.09 \mathrm{mg} / \mathrm{L}$ 
Samples for $\mathrm{BOD}_{5}$ analysis also were taken from three surface locations in the Fall Creek Pond on August 21, 1980, to determine the effect of summer storm inflow. The results of analysis indicated an average $\mathrm{BOD}_{5}$ of about $2 \mathrm{mg} / \mathrm{L}$ in the unfiltered samples and about $1 \mathrm{mg} / \mathrm{L}$ in the filtered samples. It is anticipated that the Bridge Creek impoundment would have similar BOD conditions in its surface waters.

DO and temperature profiles were measured in the Fall Creek Pond on July 10, 1980. It was one of the warmest days during the summer and probably represents the most critical $\mathrm{DO}$ and water-temperature conditions that occurred that year. Clams were observed floating on the surface and the water had a slight green tint due to the algae present. DO and temperature data are presented in table 8 .

The Fall Creek Pond has a surface spillway, but no bottom-draw outlet. A bottom draw in the Bridge Creek outlet would probably reduce the buildup of oxygen-demanding material that depleted the Fall Creek Pond's bottom water oxygen. Because the Bridge Creek basin has less agricultural use than Fall Creek's, it might be expected that the Bridge Creek impoundment would not exhibit as severe an algae bloom.

Another indication of the conditions to expect in the proposed impoundment is provided by the conditons in the previous impoundment. Before 1954 an impoundment existed on Bridge Creek on the same site as that proposed. Records from a 1953 weed and depth survey indicate that sedimentation and emergent aquatic weed growth occurred near the inflow point of the impoundment. It would therefore seem likely that the upstream end of the proposed impoundment would have similar sedimentation problems.

The previously mentioned comparison of nutrient concentrations for a nearby impoundment and historical records provide useful qualitative information. However, to quantitatively predict the resulting dissolved oxygen and temperature conditions in the proposed impoundment this study used a computer model.

\section{COMPUTER SIMULATION OF PROPOSED IMPOUNDMENT WATER TEMPERATURE AND DISSOLVED OXYGEN}

The temperature and DO conditions in the proposed impoundment were simulated using the Corps of Engineers' "Thermal Simulation of Lakes" programs (1974). The reservoir model was modified for use on a small shallow impoundment such as that proposed. The model divides the impoundment pool into a series of equal thickness horizontal layers, with each layer representing a different depth zone. Temperature and DO is transferred between layers by both diffusive and convective mixing processes. Inflow is placed in the appropriate pool layer according to density, and outflow is withdrawn from a user-specified withdrawal layer.

The model operates on a daily simulation interval. Output therefore reflects daily average values. The input data requirements are daily average values of streamflow, inflowing $D O$ concentration, and inflow BOD data. The thermal simulation requires daily values of shortwave radiation, equilibrium air 
Table 8. DO and temperature in the Fall Creek impoundment, July 10, 1980

\begin{tabular}{|c|c|c|c|c|c|}
\hline \multicolumn{3}{|c|}{$\begin{array}{l}100 \text { yards upstream from dam } \\
\text { Time }=1200 \text { hours (noon) }\end{array}$} & \multicolumn{3}{|c|}{$\begin{array}{c}50 \text { yards upstream from dam } \\
\text { Time }=1225 \text { hours }\end{array}$} \\
\hline $\begin{array}{l}\text { Depth below } \\
\text { surface } \\
\text { (ft) }\end{array}$ & $\begin{array}{c}\mathrm{DO} \\
(\mathrm{mg} / \mathrm{L})\end{array}$ & $\begin{array}{l}\text { Water } \\
\text { temperature } \\
\quad\left({ }^{\circ} \mathrm{C}\right)\end{array}$ & $\begin{array}{l}\text { Depth below } \\
\text { surface } \\
(f t)\end{array}$ & $\begin{array}{c}\mathrm{DO} \\
(\mathrm{mg} / \mathrm{L})\end{array}$ & $\begin{array}{l}\text { Water } \\
\text { temperature } \\
\left({ }^{\circ} \mathrm{C}\right)\end{array}$ \\
\hline $\begin{array}{c}0.0 \\
1.25 \\
2.50 \\
3.75 \\
5.00 \\
6.25 \\
7.50 \\
8.75 \\
10.00\end{array}$ & $\begin{array}{r}11.4 \\
11.2 \\
10.8 \\
9.6 \\
6.2 \\
3.6 \\
1.6 \\
.2 \\
.1\end{array}$ & $\begin{array}{l}28.0 \\
28.0 \\
27.0 \\
26.0 \\
25.5 \\
25.0 \\
24.0 \\
22.5 \\
21.0\end{array}$ & $\begin{array}{r}0.0 \\
1.0 \\
2.0 \\
3.0 \\
4.0 \\
5.0 \\
6.0 \\
7.0 \\
8.0 \\
9.0 \\
10.0\end{array}$ & $\begin{array}{r}11.6 \\
11.5 \\
11.6 \\
9.4 \\
8.1 \\
6.0 \\
2.7 \\
.7 \\
.2 \\
.2 \\
.1 \\
\text { (BOTTOM) }\end{array}$ & $\begin{array}{l}28.5 \\
28.5 \\
28.0 \\
26.5 \\
26.0 \\
25.5 \\
25.0 \\
23.5 \\
22.0 \\
21.0 \\
20.5\end{array}$ \\
\hline
\end{tabular}

NOTE: The saturation DO concentration at $28^{\circ} \mathrm{C}$ is about $7.5 \mathrm{mg} / \mathrm{L}$. The observed supersaturation is due to photosynthetic algae activity.

temperature, and the water-surface heat-exchange coefficient. The required meteorologic data were obtained from the Federal Aviation Administration's weather station at Eau Claire, located $23 \mathrm{mi}$ northwest of Augusta.

other input to the model includes the impoundment's geometry in the form of storage-elevation curve and the outlet layer location. A bottom-draw outlet capacity can be specified in conjunction with a surface-level outlet layer. Sediment oxygen demand and biologic productivity-induced BOD values can also be specified for use with the Do simulation.

Output from the model consists of temperature and DO depth profiles of the impoundment for specified days. A dally summary of the outflowing water temperature and $D O$ is provided for each day of simulation.

Recorded streamflow, DO, and temperature data for the period of July 8 to August 7, 1980, was used as input to the computer programs to estimate what conditions would have existed had the proposed dam on Bridge Creek been in place during that period. This period was selected as having the summer's most critical flow, temperature, and DO conditions. 
Table 9. Comparison of simulated impoundment temperature and DO for Bridge Creek, July 11, 1980

\begin{tabular}{lcccccc}
\hline \multicolumn{2}{c}{ With surface-level outlet } & & \multicolumn{2}{c}{ With bottom-level outlet } \\
\cline { 5 - 6 } $\begin{array}{l}\text { Depth } \\
(\mathrm{ft})\end{array}$ & $\begin{array}{c}\text { Temperature } \\
\left({ }^{\circ} \mathrm{C}\right)\end{array}$ & $\begin{array}{c}\text { Do } \\
(\mathrm{mg} / \mathrm{L})\end{array}$ & & $\begin{array}{c}\text { Depth } \\
(\mathrm{ft})\end{array}$ & $\begin{array}{c}\text { Temperature } \\
\left({ }^{\circ} \mathrm{C}\right)\end{array}$ & $\begin{array}{c}\text { Do } \\
(\mathrm{mg} / \mathrm{L})\end{array}$ \\
\hline & & & & & \\
0.0 & 26.5 & 8.2 & 0.0 & 26.8 & 8.1 \\
1.0 & 26.1 & 8.2 & 1.0 & 26.7 & 8.1 \\
2.0 & 25.2 & 5.7 & 2.0 & 26.4 & 7.8 \\
3.0 & 24.2 & 5.5 & 3.0 & 26.1 & 6.5 \\
4.0 & 23.7 & 5.5 & 4.0 & 25.5 & 5.9 \\
5.0 & 23.3 & 5.5 & 5.0 & 24.4 & 5.7 \\
6.0 & 23.1 & 5.5 & 6.0 & 23.6 & 5.7 \\
7.0 & 23.0 & 5.0 & 7.0 & 23.3 & 5.0 \\
8.0 & 23.0 & 4.3 & 8.0 & 23.0 & \\
\hline
\end{tabular}

NOTE: These values represent the simulated average conditions for the day. Photosynthetic algae could increase the surface Do during daylight hours. The water temperature would be warmer during midafternoon and cooler during the morning.

For simulation purposes, the impoundment pool was assumed to be held constant at its normal design elevation of $92.5 \mathrm{ft}$ (local datum). Water outflows were assumed to equal inflows. Surface oxygen saturation and DO constants were based on those observed for the Fall Creek Pond. The initial impoundment temperature and DO profiles assumed values equal to the inflowing water. The simulation was run twice to compare effects; once with a bottom draw and once with a surface level outlet. In neither case did the reservolr stratify.

The computer simulation of both outlet types indicated that the warmest impoundment water temperature would have occurred on July 11 . A comparison of the simulated temperature and DO with depth for both outlet types is shown in table 9.

These results indicate little difference in temperature within the impoundment using surface- or bottom-draw outlets. Dissolved-oxygen impoundment conditions are slightly better overall with the bottom-draw outlet. However, differences in the downstream release water temperatures and DO is more pronounced. Comparative values of inflowing and outflowing water temperature and DO are shown in table 10 for both outlet configurations.

The average inflowing water temperature for the simulated period was $20.9^{\circ} \mathrm{C}$, with an average DO concentration of $7.1 \mathrm{mg} / \mathrm{L}$. 
Table 10. Comparison of simulated daily average outflow temperature and DO

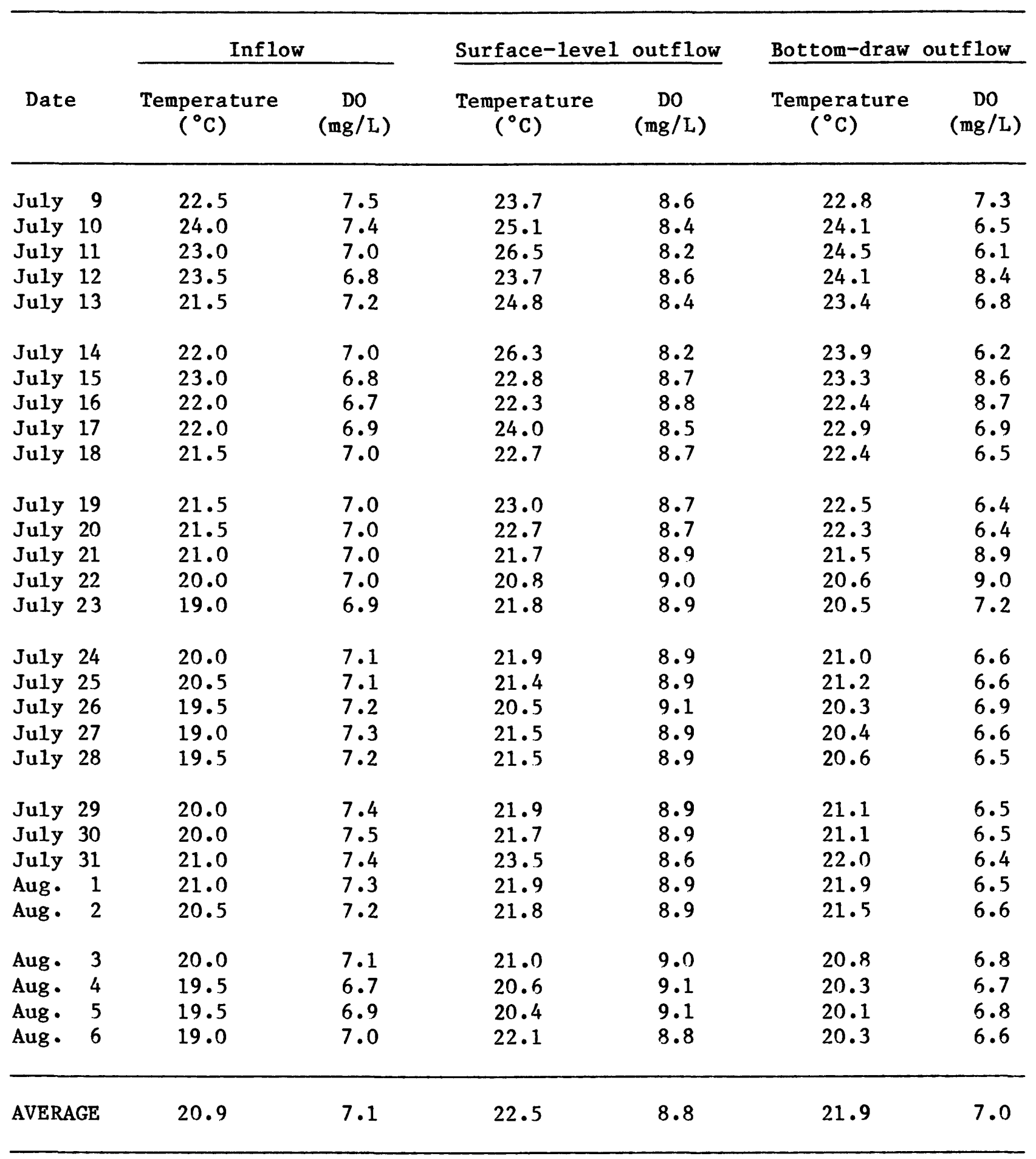


The simulated surface-level outflow condition results in an average release water temperature of $22.5^{\circ} \mathrm{C}$, and an average $\mathrm{DO}$ of $8.8 \mathrm{mg} / \mathrm{L}$. The average rise in the outflow temperature is $1.6^{\circ} \mathrm{C}$ above that of the day's inflow. The greatest rise (of $4.3^{\circ} \mathrm{C}$ ) occurs on July 14 , although the warmest average outflow temperature $\left(26.5^{\circ} \mathrm{C}\right.$ ) occurs on July 11 with a rise of $3.5^{\circ} \mathrm{C}$ above the inflow temperature. The impoundment surface layer was specified at 100 percent DO saturation for simulation purposes. This was done to simulate the effects of atmospheric reaeration and photosynthetic algae effects, based on Fall Creek Pond conditions.

The simulated bottom-draw outflow condition results in an average release water temperature of $21.9^{\circ} \mathrm{C}$, and an average DO concentration of $7.0 \mathrm{mg} / \mathrm{L}$. The average outflow temperature of $21.9^{\circ} \mathrm{C}$ is $1.6^{\circ} \mathrm{C}$ cooler than the average surfaceleve 1 outflow temperature, but is still an average of $0.9^{\circ} \mathrm{C}$ above the inflow temperature. The temperature rise is due to the inflow water mixing with the warmer impoundment water before being drawn off the bottom. The greatest rise (of $1.9^{\circ} \mathrm{C}$ ) occurs on July 13 and 14 , although the warmest outflow temperature $\left(24.5^{\circ} \mathrm{C}\right)$ still occurs on July 11.

The slight decrease in $D O$ is due to a sediment-oxygen-demand effect as the inflow moves across the pool bottom toward the outlet. The simulated outflow DO concentration does not consider any aeration device at the outlet.

The computer simulation indicates the inflowing water will sink to the bottom of the pool and move toward the dam. With a surface-level outlet it would take 3 days for the inflow to upwell and be drawn off from the surface. With a bottom-draw outlet the inflow would exit the impoundment in 1 day. Transit times were computed assuming an average flow of $7.5 \mathrm{ft}^{3} / \mathrm{s}$, and normal elevation pool storage.

Based on the computer simulation, it might be advantageous to have a bottomdraw outlet. Downstream release temperatures would be cooler, and residence time of inflowing water would be less than with a surface-level outlet. However, using a bottom-draw outlet may increase algal problems due to the longer detention of water near the surface.

\section{SIMULATION OF DOWNSTREAM EFFECTS}

Based on the simulated outflow results in table 10 , the Do in the outflow should be at or near saturation with a surface-level outlet and above $6.0 \mathrm{mg} / \mathrm{L}$ with a bottom-draw outlet.

The U.S. Geological Survey's G301 Steady State Excess Temperature Model was used to simulate the cooling of the impoundment release as it flowed downstream. Input to the computer program consists of excess water temperature, ambient air temperature, wind speed, stream-channel cross-section data, and flow traveltime to the desired downstream end point.

The simulated outflow temperatures in table 10 are higher than the natural temperatures that would exist in the stream. This difference (excess 
temperature) would decrease as the water flowed downstream and cooled off. Eventually, the water temperature would return to the natural temperature somewhere downstream.

The application of the model indicated that the water temperature would not cool off more than $1^{\circ} \mathrm{C}$ by the time the flow reached the Thompson Valley Creek inflow point.

\section{SUMMARY AND CONCLUSIONS}

The streamflow and water-quality data were collected for Bridge Creek near Augusta, Wis., for the 1980 water year. The average daily flow was about $50 \mathrm{ft}^{3} / \mathrm{s}$, with the maximum flow of $1,010 \mathrm{ft}^{3} / \mathrm{s}$ occurring on September 21,1980 , and probable minimum flow of less than $4.5 \mathrm{ft}^{3} / \mathrm{s}$ occurring during early March under ice conditions. Natural water temperature reached $26.0^{\circ} \mathrm{C}$ during the summer of 1980 and Do concentrations were as 1 ow as $6.0 \mathrm{mg} / \mathrm{L}$.

Computer simulation of the proposed impoundment indicated that the reservoir would not stratify or become anaerobic at the bottom. The computed transit time of inflowing water under base-flow conditions (about $7.5 \mathrm{ft} / \mathrm{s}$ ) would be 3 days with a surface-level outlet, or 1 day with a bottom-draw outlet. The proposed impoundment would probably have some algae problems during the summer, based on nutrient samples collected from Bridge Creek during March, April, and July 1980. The nearby Fall Creek impoundment currently exhibits such problems during the summer. The Bridge Creek impoundment is not expected to have such severe problems since the inflow has lower nutrient concentrations than Fa11 Creek's inflow. Some sedimentation is expected to occur at the inflow point to the proposed impoundment, although not as severe as the Fal1 Creek impoundment.

Computer simulation of flow at the outlet of the proposed impoundment indicates that the average water temperature would rise above the inlet temperature $1.6^{\circ} \mathrm{C}$ with a surface-level reservoir outlet, or $1.0^{\circ} \mathrm{C}$ with a bottom-draw reservoir outlet.

On extremely warm days the water temperature of releases from the dam may increase up to $3.5^{\circ} \mathrm{C}$ above natural conditions if a surface-level outlet is used, or $1.5^{\circ} \mathrm{C}$ if a bottom draw is used. As the water flows downstream it would cool. However, a computer temperature model results showed that the temperatures would not be reduced more than $1^{\circ} \mathrm{C}$ before the water reached Thompson Valley Creek.

The downstream Do concentration would be near saturation with a surfacelevel outlet, and somewhat lower with a bottom-draw outlet. In either case, the outflow Do would equal or exceed $6.0 \mathrm{mg} / \mathrm{L}$ during the period simulated.

\section{REFERENCES}

Bauer, D. P., and MacKenroth, E., 1974, One dimensional stream excess temperature analysis, program no. G301: U.S. Geologica1 Survey Computer Program Documentation User's Manual. 
Holmstrom, B. K., 1979, Low-flow characteristics of Wisconsin streams at sewagetreatment plants and industrial plants: U.S. Geological Survey

Water-Resources Investigations 79-31, $123 \mathrm{p}$.

Owen Ayres \& Associates, Inc., 1972, Preliminary engineering report on Bridge Creek Dam at Augusta, Wisconsin: $17 \mathrm{p}$.

U.S. Corps of Engineers, 1974, Thermal simulation of lakes: U.S. Army Engineer District, Baltimore, Maryland, Program No. 722-F5-E1010 and 722-F5-E1011.

Skougstad, M. W., Fishman, M. J., Freidman, T. C., Erdman, D. E., and Duncan, S. S., 1979, Methods for determination of inorganic substances in water and fluvial sediments: Techniques for Water Resources Investigations, Book 5, Chapter Al. 